\title{
Isolasi Bacillus thuringiensis Lokal dari Tanah Kota Bandung Berdasarkan Ketinggian
}

\author{
Sunarjati Sudigdoadi, ${ }^{1}$ Hadyana Sukandar, ${ }^{2}$ Lia Faridah $^{1}$ \\ ${ }^{1}$ Departemen Mikrobiologi dan Parasitologi Fakultas Kedokteran Universitas Padjadjaran \\ ${ }^{2}$ Departemen Ilmu Kesehatan Masyarakat Fakultas Kedokteran Universitas Padjadjaran
}

\begin{abstract}
Abstrak
Demam dengue (DD) merupakan penyakit endemis di negara berkembang termasuk Indonesia. Kasus DD di Kota Bandung mencapai angka tertinggi di antara kota lain di Jawa Barat, yaitu sebesar 1.180 kasus. Belum ditemukan obat yang tepat dalam menangani infeksi ini. Walaupun sudah ditemukan vaksin, namun penggunaan vaksin ini masih terbatas pada usia dan kalangan tertentu. Dengan demikian, pengendalian vektor baik secara kimiawi maupun biologis, masih menjadi prioritas. Salah satu agen biologis untuk mengendalikan populasi larva nyamuk adalah Bacillus thuringiensis (Bt). Penelitian dilakukan selama bulan Januari-Desember 2015. Penelitian ini merupakan suatu eksperimen dengan rancangan faktorial yang bertujuan mendapatkan isolat $B t$ dari tanah di berbagai ketinggian di Kota Bandung. Sampel tanah diambil dari ketinggian 600 m, 800 m, serta $1000 \mathrm{~m}$ dan setiap ketinggian diambil 3 lokasi dengan metode acak. Bt diisolasi dengan medium selektif. Isolat bakteri yang diperoleh kemudian diidentifikasi dengan pewarnaan gram, pengamatan endospora subterminal, uji fermentasi glukosa, sitrat, indol, dan manitol. Kelimpahan Bt di tiap ketinggian dihitung menggunakan $B t$ index. Hasil identifikasi mendeteksi terdapat 3 isolat yang menunjukkan kemiripan dengan $B t$, yaitu isolat STBD.2.02, CBRM.3.01, dan KOPO.3.02. Nilai Bt index menunjukkan kelimpahan Bt di ketinggian $800 \mathrm{~m}$ lebih tinggi dibanding dengan ketinggian yang lain. [MKB. 2017;49(2):110-4]
\end{abstract}

Kata kunci: Bacillus thuringiensis lokal, Bandung, ketinggian, tanah

\section{Local Bacillus thuringiensis Isolation from Bandung Soil by Altitude}

\begin{abstract}
Dengue fever (DF) is an endemic disease in developing countries including Indonesia. Bandung has the highest number of Dengue Fever in West Java Province with 1,180 cases. There is currently no drugs or vaccines that can prevent dengue fever and dengue hemorrhagic fever, making vector control, both chemically and biologically, the primary prevention approach. One biological agent that has been used to control the larval population is Bacillus thuringiensis (Bt). This study is an experimental study with factorial design aimed to obtain Bt isolates from soil of various altitude around Bandung city area period January to December 2015. Soil samples were acquired from $600 \mathrm{~m}, 800 \mathrm{~m}$ and 1,000 m above sea level. Sampling was conducted randomly from 3 points at every altitude. Bt were isolated with a selective medium. The acquired bacteria samples were then identified using gram stain, subterminal endospore observation, as well as glucose fermentation, citrate, indole, and manitol tests. Bt abundance for each altitude was calculated using Bt index. Three isolates with similarity with Bt were identified, i.e. STBD 2.02, CBRM 3.01 and KOPO 3.02 isolates. Bt index value indicates that the abundance of Bt at $800 \mathrm{~m}$ altitude is the highest compared to others. [MKB. 2017;49(2):110-4]
\end{abstract}

Key words: Altitude, Bandung, local Bacillus thuringiensis, soil

Korespondensi: Dr. Sunarjati Sudigdoadi, dr., MS., Sp MK, Departemen Mikrobiologi dan Parasitologi Fakultas Kedokteran Universitas Padjadjaran, E-mail: titi_sa@hotmail.com 


\section{Pendahuluan}

Demam dengue (DD) adalah penyakit menular yang disebabkan oleh virus dengue kelompok arbovirus, genus flavivirus famili flavividae. Penyakit ini adalah penyakit endemis. Angka kejadian penyakit (incidence rate) dan angka kematian penderita (case fatality rate) per tahun masih cukup tinggi. ${ }^{1}$ Berdasar atas data dari Kementerian Kesehatan, jumlah kasus DD di Indonesia pada tahun 2010 ada 150.000 kasus. Dengan jumlah kematian sekitar 1.317 orang pada tahun 2010, Indonesia menduduki urutan tertinggi kasus demam dengue di kawasan Asia Tenggara. Kasus DD di Indonesia paling banyak terjadi di kota besar seperti Jakarta, Surabaya, dan Bandung. ${ }^{2}$

Kepala Dinas Kesehatan Provinsi Jawa Barat telah memaparkan angka kasus DD di Provinsi Jawa Barat dari tahun 2010 hingga tahun 2011 mengalami penurunan. Namun, kasus DD di Kota Bandung merupakan angka yang tertinggi di antara berbagai kota/kabupaten di Provinsi Jawa Barat, dengan 1.180 kasus di Kota Bandung. ${ }^{2}$ Dengan demikian, dibutuhkan upaya menyeluruh tidak hanya tentang pengobatan. Perlu ditingkatkan upaya untuk pengendalian demam berdarah, baik pencegahan maupun penanggulangan. Strategi yang utama adalah meningkatkan kesadaran masyarakat akan bahaya demam dengue dan cara pencegahannya.

Secara universal saat ini belum ada obat yang cepat dalam menangani infeksi virus dengue. Selain itu, penggunaan vaksin ini masih terbatas pada usia dan kalangan tertentu. Pengendalian penyebaran virus dengue adalah memutus rantai penularan, salah satunya dengan mengendalikan vektor virus dengue, yaitu nyamuk betina Aedes aegypty dan Aedes albopictus. Upaya pengendalian vektor yang digunakan untuk program pengendalian DD antara lain dengan pengendalian kimiawi dan juga pengendalian biologis. ${ }^{1}$

Pengendalian secara biologis merupakan suatu upaya pemanfaatan agen biologis untuk pengendalian vektor DD. Keunggulan pada agen biologis ini tidak mempunyai pengaruh negatif terhadap lingkungan dan manusia., ${ }^{3,4}$ Salah satu agen biologis yang sudah digunakan dan terbukti mampu mengendalikan populasi larva adalah Bacillus thuringiensis $(B t)^{4-8}$

$B t$ dapat ditemukan di berbagai belahan bumi karena merupakan bakteri yang hidup di alam terutama di dalam tanah. Bt dapat diisolasi dari tanah pertanian, tanah perkebunan, bangkai serangga, dan dedaunan. ${ }^{8}$ Meskipun demikian, habitat normal bakteri ini adalah di dalam tanah. Bakteri ini tumbuh secara alami sebagai saprofit yang memperoleh makanan dari sisa pembusukan materi organik, ${ }^{5,9-11}$ Tetapi belum pernah dilakukan upaya eksplorasi untuk dapat menemukan isolat lokal di Kota Bandung.

\section{Metode}

Penelitian ini adalah penelitian eksperimental dengan rancangan faktorial. Faktorial pertama adalah perlakuan terhadap sampel tanah dan faktorial kedua adalah ketinggian tanah. Penelitian dilakukan selama satu tahun, yaitu Januari-Desember 2015. Sampel tanah dikoleksi dari 9lokasi di Kota Bandung. Lokasi pengambilan sampel tanah diambil secara acak dari 3 lokasi berdasar ketinggian tempat, yaitu ketinggian $600 \mathrm{~m}$ di atas permukaan laut (Cibereum, Kopo, Cibaduyut), ketinggian $800 \mathrm{~m}$ di atas permukaan laut (Buah Batu, Tegalega, Gegebage), dan ketinggian $1.000 \mathrm{~m}$ di atas permukaan laut (Curug Dago, Setiabudi, Sukajadi). Setiap lokasi yang dipilih diambil kurang lebih 100 gram sampel tanah dan dimasukkan ke dalam wadah plastik. Diberi label berisi keterangan waktu dan lokasi pengambilan. Sebelum diisolasi, sampel tanah disimpan pada suhu $4^{\circ} \mathrm{C}$.

Sampel tanah ditimbang $25 \mathrm{~g}$ dan juga disuspensikan ke dalam $225 \mathrm{~mL}$ larutan $\mathrm{NaCl}$ $0,85 \%$ steril, setelah itu dipanaskan pada suhu $80^{\circ} \mathrm{C}$ selama 15 menit. Suspensi tersebut selanjutnya diencerkan dengan $\mathrm{NaCl}$ 0,85\% untuk membuat seri pengenceran $10^{-1}-10^{-6}$. Dari tiap pengenceran diambil sebanyak 0,1 mL kemudian diinokulasikan secara spread plate pada medium selektif $B t$ dengan komposisi: glukosa $3 \mathrm{~g},\left(\mathrm{NH}_{4}\right)_{2} \mathrm{SO}_{4} 2 \mathrm{~g}$, yeast extract $2 \mathrm{gr}$, $\mathrm{K}_{2} \mathrm{HPO}_{4} \cdot 3 \mathrm{H}_{2} \mathrm{O} 0,08 \mathrm{~g}, \mathrm{MgSO} 40,096 \mathrm{~g}$, $\mathrm{CaCl} 2.2 \mathrm{H}_{2} \mathrm{O}$ $0,08 \mathrm{~g}, \mathrm{MnSO} 40,03 \mathrm{~g}$, agar $15 \mathrm{~g}$ dalam $1.000 \mathrm{ml}$ akuades ${ }^{11}$ selanjutnya diinkubasikan pada suhu $30^{\circ} \mathrm{C}$ selama $2-4$ hari.

Setelah diinkubasi, dipilih beberapa koloni dari setiap pengenceran yang menunjukkan ciriciri morfologi koloni yang diduga sebagai $B t$, yaitu koloni berbentuk bulat, tepian berkerut, memiliki diameter 5-10 mm, berwarna putih, elevasi timbul dan permukaan koloni kasar, sel gram positif, berbentuk batang, serta terdapat endospora subterminal. ${ }^{3,11}$ Dilakukan subkultur dari koloni yang terpisah pada medium selektif $B t$ dan diinkubasi pada suhu $30^{\circ} \mathrm{C}$ selama $24-48$ jam. Isolat yang terpilih kemudian diidentifikasi menggunakan uji biokimia terdiri atas uji fermentasi glukosa, sitrat, indol, dan manitol. 

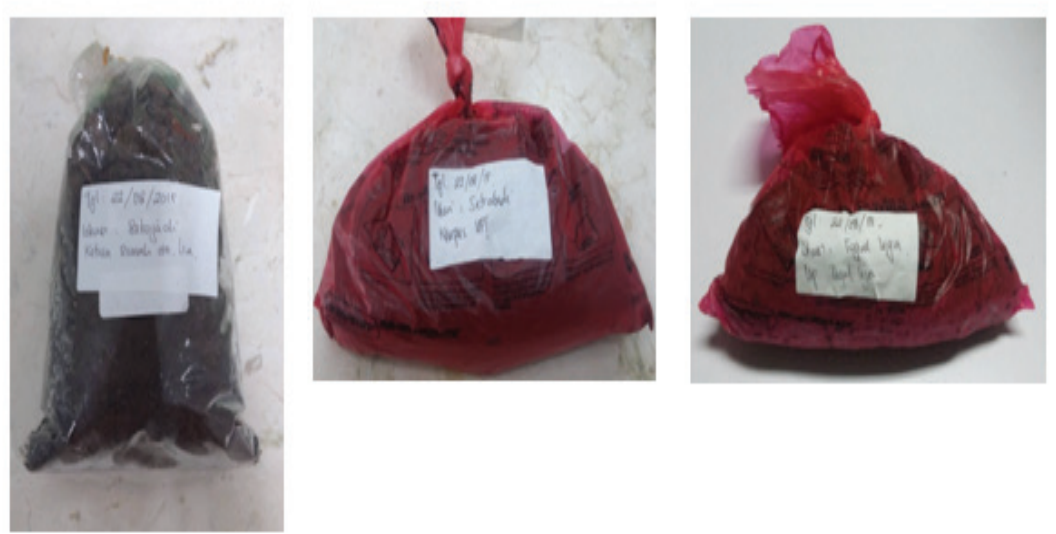

\section{Gambar 1 Sampel Tanah untuk Isolasi $B t$}

\section{Hasil}

Diperoleh sebanyak 9 sampel tanah untuk isolasi Bt yang berasal dari 9 daerah di Kota Bandung berdasar atas ketinggian wilayahnya, yaitu Cibereum, Kopo, Cibaduyut (ketinggian $600 \mathrm{~m}$ di atas permukaan laut); Buah Batu, Tegalega, Gegebage (ketinggian $800 \mathrm{~m}$ di atas permukaan laut) dan Curug Dago, Setiabudi, Sukajadi (ketinggian $1.000 \mathrm{~m}$ di atas permukaan laut). Sampel tanah pengenceran $10^{-1}-10^{-6}$ diinokulasi ke dalam medium agar dan diinkubasi selama

\section{Tabel 1 Isolat Bakteri dari Tanah Kota} Bandung

\begin{tabular}{|c|c|c|c|}
\hline \multirow{2}{*}{$\begin{array}{c}\text { Ketinggian } \\
\text { (m) }\end{array}$} & \multirow{2}{*}{$\begin{array}{c}\text { Lokasi } \\
\text { Sampel }\end{array}$} & \multicolumn{2}{|c|}{ Kode Isolat } \\
\hline & & SKJD.4.01 & SKJD.4.04 \\
\hline & & SKJD.4.02 & SKJD.4.05 \\
\hline & & SKJD.4.03 & SKJD.6.01 \\
\hline & Setiabudi & STBD.2.01 & STBD.2.05 \\
\hline & & STBD.2.02 & STBD.3.01 \\
\hline & & STBD.2.04 & \\
\hline & Curug Dago & CRDG.1.01 & CRDG.1.04 \\
\hline & & CRDG.1.02 & CRDG.2.01 \\
\hline & & CRDG.1.03 & CRDG.2.02 \\
\hline \multirow[t]{3}{*}{800} & Tegalega & TGLG.6.01 & TGLG.6.02 \\
\hline & Gedebage & GDBG.5.01 & \\
\hline & Buahbatu & ВНВТ.3.01 & \\
\hline \multirow[t]{4}{*}{600} & Коро & KOР0.3.01 & КОР0.4.01 \\
\hline & & KOP0.3.02 & \\
\hline & Cibeureum & CBRM.3.01 & CBRM.3.02 \\
\hline & Cibaduyut & CBDT.3.01 & CBDT.4.01 \\
\hline
\end{tabular}

24-48 jam, kemudian dipilih isolat bakteri yang menunjukkan ciri-ciri fenotip seperti $B t$.

Diperoleh total 30 isolat bakteriyang mirip dengan Btdarisampel tanah di Kota Bandung (Tabel 1). Isolat bakteri tersebut kemudian diuji biokimia untuk mengetahui isolat yang memiliki kemiripan sifat-sifat biokimia dengan Bt.

Hasil uji fermentasi glukosa, sitrat dan indol menunjukkan terdapat 3 isolat bakteri yang menghasilkan reaksi positif dari total 30 isolat yang diuji, yaitu isolat STBD.2.02 dari ketinggian 1.000 m, isolat CBRM.3.01 dari ketinggian 600 $\mathrm{m}$, dan isolat KOPO.3.02 dari ketinggian 600 m. Selanjutnya, dilakukan uji manitol terhadap ketiga isolat tersebut sebagai uji konfirmasi.

Hasil di atas menunjukkan bahwa isolat STBD. 2.02, CBRM.3.01, dan KOPO.3.02 menunjukkan hasil positif untuk uji manitol.

\section{Pembahasan}

Sebanyak 30 isolat bakteri dengan karakter fenotip mirip Bt diperoleh dari 9 lokasi di Kota Bandung berdasar atas ketinggian tempat (Tabel 1). Jumlah isolat yang diperoleh bervariasi dari tiap-tiap lokasi, pada lokasi dengan ketinggian $1.000 \mathrm{~m}$ diperoleh 17 isolat, pada ketinggian 800 m diperoleh 4 isolat, sedangkan di ketinggian $600 \mathrm{~m}$ diperoleh 9 isolat.

Lokasi sampling dengan ketinggian yang berbeda di Kota Bandung memiliki $B t$ index yang berbeda. Bt index adalah nilai perbandingan total isolat $B t$ dengan total isolat Bacillus spp. untuk menunjukkan kelimpahan $B t .{ }^{11}$ Bt index pada ketinggian $1000 \mathrm{~m}$ sebesar 0,06 , ketinggian 800 $\mathrm{m}$ sebesar 0,08 dan ketinggian $600 \mathrm{~m}$ sebesar 0,06 . Berdasarkan atas nilai $B t$ index tersebut 
Sunarjati Sudigdoadi: Isolasi Bacillus thuringiensis Lokal dari Tanah Kota Bandung Berdasarkan Ketinggian

Tabel 2 Hasil Uji Fermentasi Glukosa, Sitrat, dan Indole

\begin{tabular}{|c|c|c|c|c|}
\hline \multirow[b]{2}{*}{ Kode Isolat } & \multicolumn{3}{|c|}{ Uji Biokimia } & \multirow[b]{2}{*}{ Simpulan } \\
\hline & $\begin{array}{c}\text { Fermentasi } \\
\text { Glukosa }\end{array}$ & Sitrat & Indol & \\
\hline Kontrol Positif & - & + & - & \\
\hline SKJD.4.01 & - & - & - & Negatif \\
\hline SKJD.4.02 & - & - & - & Negatif \\
\hline SKJD.4.03 & - & - & - & Negatif \\
\hline SKJD.4.04 & - & - & - & Negatif \\
\hline SKJD.4.05 & - & - & - & Negatif \\
\hline SKJD.6.01 & - & - & - & Negatif \\
\hline STBD.2.01 & - & - & - & Negatif \\
\hline STBD.2.02 & - & + & - & Positif \\
\hline STBD.2.04 & - & - & - & Negatif \\
\hline STBD.2.05 & - & - & - & Negatif \\
\hline STBD.3.01 & - & - & - & Negatif \\
\hline CRDG.1.01 & - & - & - & Negatif \\
\hline CRDG.1.02 & - & - & - & Negatif \\
\hline CRDG.1.03 & - & - & - & Negatif \\
\hline CRDG.1.04 & - & - & - & Negatif \\
\hline CRDG.2.01 & - & - & - & Negatif \\
\hline CRDG.2.02 & - & - & - & Negatif \\
\hline TGLG.6.01 & - & - & - & Negatif \\
\hline TGLG.6.02 & - & - & - & Negatif \\
\hline CBDT.3.01 & - & - & - & Negatif \\
\hline CBDT.3.02 & - & - & - & Negatif \\
\hline CBDT.4.01 & - & - & - & Negatif \\
\hline CBDT.5.01 & - & - & - & Negatif \\
\hline CBRM.3.01 & - & + & - & Positif \\
\hline CBRM.3.02 & - & - & - & Negatif \\
\hline GDBG.5.01 & - & - & - & Negatif \\
\hline ВHBT.3.01 & - & - & - & Negatif \\
\hline КОРО.3.01 & - & - & - & Negatif \\
\hline КОРО.3.02 & - & + & - & Positif \\
\hline KOPO.4.01 & - & - & - & Negatif \\
\hline
\end{tabular}

Tabel 3 Uji Manitol

\begin{tabular}{|c|c|c|c|c|c|}
\hline \multirow[b]{2}{*}{ Kode Isolat } & \multicolumn{4}{|c|}{ Uji Biokimia } & \multirow[b]{2}{*}{ Simpulan } \\
\hline & $\begin{array}{c}\text { Fermentasi } \\
\text { Glukosa }\end{array}$ & Sitrat & Indol & Manitol & \\
\hline Kontrol Positif & - & + & - & - & \\
\hline STBD.2.02 & - & + & - & - & Positif \\
\hline CBRM.3.01 & - & + & - & - & Positif \\
\hline
\end{tabular}


lokasi dengan ketinggian 800 m menunjukkan nilai yang lebih tinggi bila dibanding dengan ketinggian yang lain. Hal ini berarti kelimpahan $B t$ di ketinggian $800 \mathrm{~m}$ lebih tinggi dibanding dengan ketinggian yang lain. Namun, secara keseluruhan Bt index yang diperoleh tiap lokasi terhitung masih rendah (lebih kecil dari 0,5). Dapat disimpulkan kelimpahan $B t$ dari sampel tanah di Kota Bandung masih rendah.

Berdasar atas hasil dari pewarnaan gram, pengamatan endospora subterminal, dan uji fermentasi glukosa, indol, citrate, serta manitol, terdapat 3 isolat bakteri yang memperlihatkan kemiripan karakter dengan Bt, yaitu isolat STBD.2.02 dari ketinggian 1.000 m, CBRM.3.01 dari ketinggian $600 \mathrm{~m}$, dan KOPO.3.02 dari ketinggian $600 \mathrm{~m}$. Hasil ini menunjukkan bahwa tidak semua sampel tanah di Kota Bandung mengandung $B t$, hanya ditemukan tiga isolat bakteri atau $10 \%$ dari total isolat yang diperoleh. Isolat bakteri yang ditemukan lebih sedikit dibanding dengan studi yang dilakukan oleh Tripsilla dkk. ${ }^{11}$, hal ini dapat dikarenakan sampel tanah yang diuji juga lebih sedikit.

\section{Daftar Pustaka}

1. Lucyati A. Upaya mengurangi penderita demam berdarah dengue. 2012. Tersedia dari: www. neraca. co.id.

2. Departemen Kesehatan RI. Kasus demam berdarah dengue di Indonesia tertinggi di Asean. 2012. Tersedia dari: www.kompas. com.

3. Cinar C, Apaydin O, Yenidunya AF, Harsa S, Gunes H. Isolation and Characterization of Bacillus thuringiensis strains from oliverelated Habitats in Turkey. J Appl Microbiol. 2008;104(2):515-25.
4. Assaeedi ASA, Osman GEH, Abulreesh HH. The occurrence and insecticidal activity of Bacillus thuringiensis in the arid environments. AJCS. 2011;5(10):1185-90

5. Tetreau G, Patil CD, Chandor-Proust A, Salunke BK, Patil SV, Depres L. Production of the bioinsecticide Bacillus thuringiensis subsp. Israelensis with deltamethrin increases toxicity towards mosquito larvae. Appl Microbiol. 2013;57(2):151-6.

6. Guidi V, Patocchi N, Lüthy P, Tonolla M. Distribution of bacillus thuringiensis subsp. israelensis in soil of a Swiss Wetland Reserve after 22 Years of mosquito control. Appl Environmental Microbiol. 2011;77(11): 3663-8.

7. Konecka E, Baranek J, Hrycak A, Kznowski A. Insecticidal activity of bacillus thuringiensis stains isolated from soil and water. Sci World J. 2011;2012(2012):1-5.

8. Aboussaid H, El-Aouame L, El-Messoussi S, Oufdou K. Biological activity of bacillus thurungiensis (Berliner) strians on larvae and adults of ceratitis capitata (Woedemann) (Diptera: Tephritidae). J Environmental Protection. 2010;1(4):337-45.

9. Porcar M, Perez VJ. PCR-based Identification of bacillus thuringiensis pesticidal crystal genes. FEMS Microbiol Rev. 2006; 26(5):41932.

10. Bravo A, Gómez I, Porta H, GarcíaGómez BI, Rodriguez-Almazan C, Pardo L, dkk. Minireview "evolution of bacillus thuringiensis cry toxins insecticidal activity". Microb Biotechnol. 2013;6(1):17-26.

11. Triprisila LF, Suharjono, Gama ZP, Nakagoshi N. Studi toksisitas Bacillus thuringiensis isolat lokal Jawa Timur berdasarkan ketinggian tempat terhadap larva aedes aegypti. J Biotropika. 2013;1(3):90-4. 